year to year is indicated by the Saskatchewan records as reported in The Blue Jay. Since 1942, a Saskatchewan sighting has been recorded in less than half the years to the present. Sightings in Manitoba would therefore be rarer, due to its position east of the breeding range, and irregular, as they have been in Saskatchewan. However, it is apparent that the species can be expected, at least in some years, to migrate through Manitoba, and a familiarity with the species characteristics would prepare the Manitoba birdwatcher to recognize this colourful species.

\section{Acknowledgments}

Herbert W. R. Copland and Robert W. Nero aided in locating previous Manitoba records of the Lazuli Bunting. Dr. Nero and my WNRE colleagues provided useful comments on the manuscript. R. E. Stewart is thanked for providing his extensive North Dakota records, and W. E. Godfrey for his Estevan record.

\section{LITERATURE CITED}

American Ornithologits' Union Check-list Commitee. 1957. Check-list of North American birds. 5 th ed. Lord Baltimore Press, Baltimore, Maryland. $691 \mathrm{pp}$.

Bent, A. C. 1968. Life histories of North American cardinals, buntings, towhees, finches, sparrows and allies. U.S. Natl. Mus. Bull. 237, part $1: 111-132$.

Godfrey, W. E. 1966. The birds of Canada. Natl. Mus. Can. Bull. 203, Queen's Printers, Ottawa, $428 \mathrm{pp}$.

Lawrence, A. G. 1931. "Chickadee Notes" No. 549. Winnipeg Free Press, Oct. 2.

Lawrence, A. G. 1935. "Chickadee Notes" No. 710. Winnipeg Free Press, May 31.

Lawrence, A. G. 1946. "Chickadee Notes" No. 1331. Winnipeg Free Press, November 22.

Lawrence, A. G. 1954. "Chickadee Notes" No. 1726. Winnipeg Free Press, June 18.

Mossop, H. 1955. "Chickadee Notes" No. 19. Winnipeg Free Press, May 27.

Mossop, H. 1963. "Chickadee Notes" No. 443. Winnipeg Free Press, July 13

Nero, R. W. and M. R. Lein. 1971. Birds of Moose Mountain, Saskatchewan. Sask. Nat. Hist. Soc., Spec. Publ. No. 7. 56 pp.

Peterson, R. T. 1961. A field guide to western birds. Houghton Mifflin, Boston. 2nd ed. 366 pp.

Sibley, C. G., and L. L. Short, Jr. 1959. Hybridization in the buntings (Passerina) of the Great Plains. Auk $75: 443-463$.

\title{
WESTERN GREBE FATALLY ENTANGLED IN FISHING LINE
}

by Robert W. Nero, Department of Mines, Resources and Environmental Management, Box 19, 139 Tuxedo Blvd., Winnipeg R3C OV8

Birds are affected by a host of natural and unnatural or man-made mortality factors. More than two million observations of non-hunting mortality in waterfowl, for example, were recorded in the following categories: "pollution, collisions, predation, disease, weather, and miscellaneous" (Cornwell, 1968).

Some unusual accidents have befallen Western Grebes in the Prairie Provinces: large-scale deaths due to a sudden freeze-up were noted in Alberta (Nero, 1960) ; "wetting", a break-down in the waterproofing system of plumage, and even entanglement in a rubber prophylactic ring (with probable eventual death) occurred at a sewage lagoon in Saskatchewan (Nero, 1968); and large numbers were drowned in gill-nets set for fish in Manitoba (Bartonek, 1965).
The hazard to birds of fishermen's lures and even the possibility of birds becoming entangled in fishermen's lines while the latter are fishing has been noted (Campbell, 1967). A recent observation involving a Western Grebe indicates the additional hazard of discarded lengths of fishing line.

On September 23, 1971, a dead adult Western Grebe was found floating upside down in shallow water adjacent to an earth-fill dam across a narrow inlet at the Last Mountain Lake Wildlife Area, Saskatchewan. As the photograph shows, the bird was trapped in several feet of monofilament nylon fishing line wrapped around its neck and one foot. The line was tightly drawn in two or three loops around the neck, presumably causing death by strangulation or drowning. The grebe may have become entangled in an 


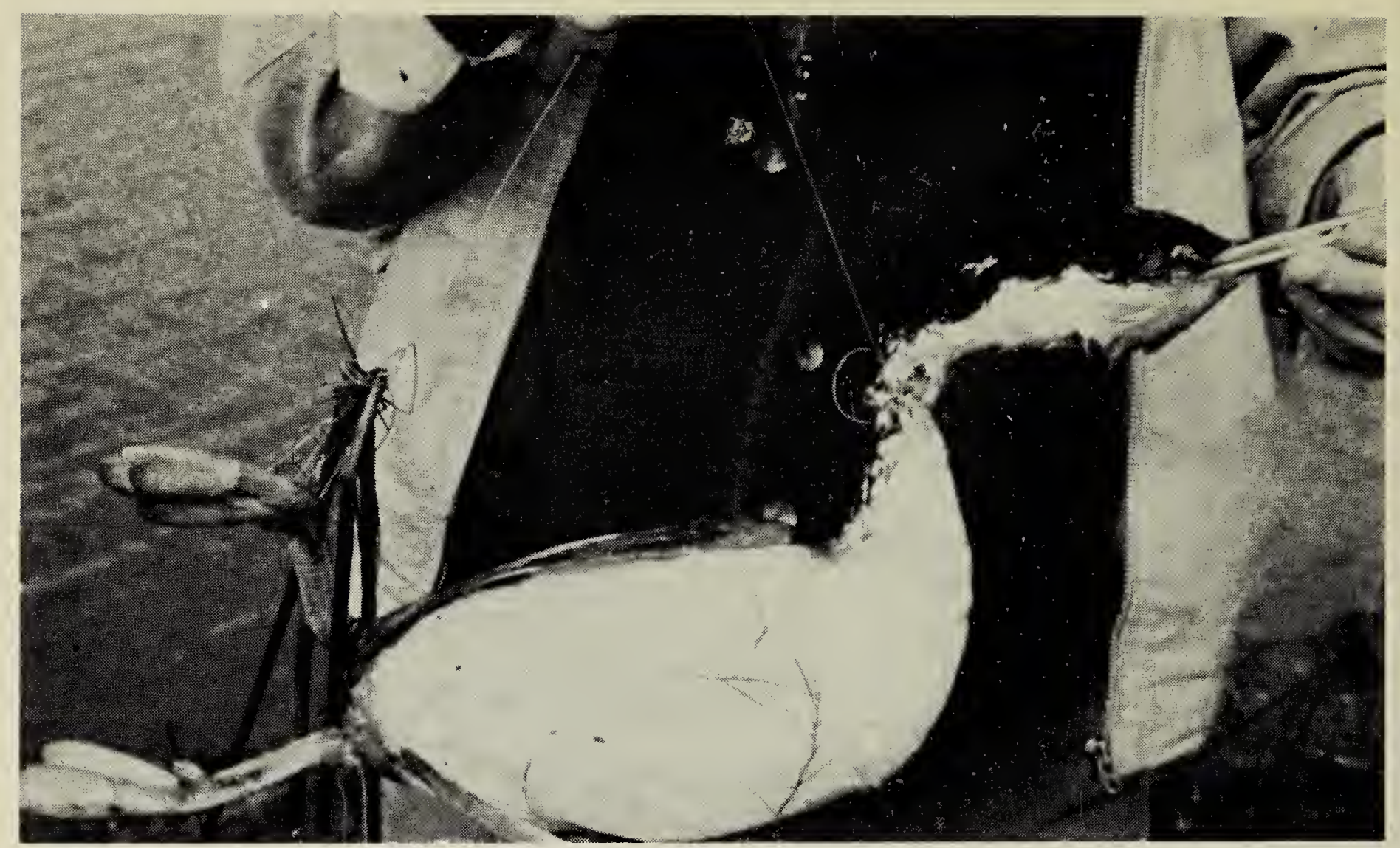

From color transparency by Gerald W. Malaher

Western Grebe fatally entangled in fishing line.

intact fishing line which was then cut loose by a fisherman. It seems more likely, however, that the bird had encountered a length of discarded and possibly tangled line.

The bay in which the grebe was found led to the open lake where numerous Western Grebes could be heard calling. A few grebes were seen diving for food close to the dam, which had recently been constructed to manag'e water levels for the benefit of waterfowl. Fishermen reportedly wère quick to take advantage of an access roadway across the dam and enjoyed good fishing from this vantage point.

A similar situation exists in Hecla Island Provincial Park in Manitoba. A recently constructed causeway between the mainland and Hecla Island on Lake Winnipeg crosses a marsh where Western Grebes have been abundant. The causeway provides a new opportunity for bird watchers as well as for fishermen. One can only urge fishermen to use some caution in fishing in areas where grebes are feeding, but perhaps it should be forbidden to throw discarded line into the water. The durability of fishing line and the tendency of monofilament line espec- ially to form loops make it a potential hazard to waterbirds. Although this is probably only a slight danger, disposal of discarded fishing line in lakes and streams is littering and as such should be discouraged.

Environmental pollutants, especially biocides, are undoubtedly more significant hazards for grebes and other fisheating birds. High levels of DDE have recently been found in eggs collected from Western Grebe colonies in the Prairie Provinces (Vermeer and Reynolds, 1970), though possible effects on reproduction are not yet known.

Thanks are due Gordon H. Staines for assistance in retrieving the grebe and Gerald W. Malaher for the use of his photograph.

\section{LITERATURE CITED}

Bartonek, J. C. Mortality of diving ducks on Lake Winripegosis through commercial fishing. Can. Field-Nat., $79: 15-20$.

Campbell, R. W. 1967. Fishing lures, a hazard to sea birds. Blue Jay, $25: 71-72$.

Cornwell, G. W. 1968. Needless duck deaths. Conservation Catalyst, $2: 15-18$.

Nero, R. W. 1960. Mass mortality of Western Grebes. Blue Jay, $18: 110-112$.

Nero, R. W. 1968. Wet waterbirds-a problem at sewage lagoons. Blue Jay, $26: 2-7$.

Vermeer, K., and L. M. Reynolds. 1970. Organochlorine residues in aquatic birds in the Canadian Prairie Provinces. Can. Field-Nat., 84 :117-129. 